DOI 10.37882/2223-2982.2020.05.34

\title{
ЯЗЫКОВАЯ ПОЛИТИКА В КАЗАХСТАНЕ
}

\section{LANGUAGE POLICY IN KAZAKHSTAN}

Jin $R u$

Summary: The development of language policy and language planning affects all aspects of public life. Text reform is one of the important contents of language ontology planning, and it can be generally divided into three categories: orthographic reform, alphabet system conversion, and alphabet character conversion. The alphabet latinization reform is a type ofalphabet system conversion. During the Soviet period, many countries, including Kazakhstan, had undergone two conversions of the Latin system and the kirilization of the main national script in the first half of the 20th century. After independence, the process of latinization of the main national scripts of Central Asian countries accelerated. Uzbekistan and Turkmenistan took the lead in reforming the latinization of scripts in 1993. The debate and discussion on the latinization of words in Kazakhstan has continued for many years. In 2012, the President of Kazakhstan Nazarbayev clearly stated in his State of the Union Address that the reform of latinization of the Kazakh alphabet should be completed by 2025. At the end of 2017, Kazakhstan officially approved the use of the Kazakh alphabet based on the Latin alphabet. However, the introduction of a brand new alphabet system will inevitably face various difficulties and may also cause unexpected results. The domestic adaptation to the new alphabet system will be a long and complicated process, and Kazakhstan will surely face the long-term coexistence of the Kirill alphabet and the Latin alphabet. The analysis of the process of latinization of Kazakhstan and its influence will have a certain reference value for the study of Kazakhstan's social culture and alphabet reform.

Keywords: Kazakhstan; alphabet reform; alphabet latinization.

\author{
Цзинь Жу \\ Ланьчжоуский университет, Китай \\ 1476174134@qq.com
}

Аннотация: Разработка языковой политики и языкового планирования влияет на все аспекты общественной жизни. Реформа письма является одним из важных элементов языкового планирования и может быть разделена на три типа: орфографическая реформа, преобразование буквенной системы и изменение характера письма. Латинизация алфавита - это тип преобразования буквенной системы. В советский период многие страны, в том числе и Казахстан, осуществили реформы два раза: буквенная латинизация и кириллизация письменности титульной нации в первой половине 20-го века. После обретения независимости процесс латинизации алфавита титульной нации стран Центральной Азии ускорился, и Узбекистан и Туркменистан возглавили в 1993 году реформу по латинизации алфавита. Дискуссия и обсуждение 0 латинизации алфавита в Казахстане продолжается уже много лет. В 2012 году первый президент Казахстана Назарбаев впервые заявил в своем послании о положении в стране, что реформа по латинизации казахского алфавита должна быть завершена к 2025 году. В конце 2017 года Казахстан официально утвердил использование казахского алфавита, который основан на латинице. Однако введение новой алфавитной системы неизбежно столкнется с рядом трудностей, а также может привести к неожиданным результатам. Внутренняя адаптация к новой алфавитной системе будет долгим и сложным процессом, и Казахстан столкнется с долгосрочным сосуществованием букв кириллицы и латиницы. Анализ процесса латинизации алфавита Казахстана и его влияния будет иметь определенное справочное значение для изучения казахстанской социальной культуры и изучения реформы графики.

Ключевые слова: Казахстан; реформа алфавита; латинизация

\section{Реформа казахского алфавита в советский перио $\Delta$ и её исторический фон}

\section{1. От арабского алфавита $\Delta$ А латинишы}

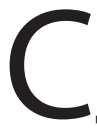

стема алфавита казахского языка за последние 100 лет изменилась дважды. С десятого до начала двадцатого века арабский алфавит официально использовался в Казахстане. Арабский алфавит содержит 29 букв и знаков, используемых для обозначения закрытых звуков. Арабский алфавит изображает персидский стиль, написанный справа налево.

В советский период на его территории было более 130 языков, относящихся к 7 языковым семьям, включая индоевропейскую, алтайскую, уральскую, сино-тибетскую, семитискую и камитическую. До Октябрьской революции только более 30 этнических групп, включая казахскую, русскую, грузинскую, армянскую, узбекскую, азербайджанскую, татарскую и туркменскую, имели письменность. Кроме того, некоторые этнические группы использовали письменность, онованную на арабице, такие как кыргызы, башкиры и др. В период октябрьской революции ситуация письменности этнических групп СССР была такой: некоторые этнические группы, такие как русская, украинская, грузинская и др., имели систему письма, соответствующую их языкам. Казахская, татарская, узбекская и таджикская письменности были основаны на арабском алфавите. Кроме того, более 50 этнических групп не имели своих письменностей до Октябрьской революции. [1]

От успеха Октябрьской революции до 1936 года эти 19 лет были периодом латинизации письменностей различных этнических групп СССР. Советское правительство провело реформу латинизации алфавита, в первую очередь потому, что латинизация способствовала единству народов великих держав, а также через алфавит очертила границы между всеми «советскими» и «несоветскими» народами. Другими словами, в то время лати- 
низация служила правам и политическим целям, потому что лидеры Коммунистической партии Советского Союза с нетерпением ожидали развития Октябрьской революции в мире и активно готовились к этому. И латинизация алфавита различных этнических групп Советского Союза была одним из этапов его подготовки. Кроме того, латинский алфавит имеет явное техническое преимущество перед арабским в областях типографской работы и преподавания.

В 1924 году арабский алфавит был исправлен в соответствии с особенностями произношения казахского языка и был заменен латинским алфавитом в 1929 году. В ответ на Коммунистический Интернационал казахский алфавит перешёл на латиницу в 1929 году. Это изменение сопровождалось интенсивными внутренними дискуссиями, и вопрос о замене арабского алфавита латинским был решён только в течение трех лет с 1924 по 1927 год. В Казахстане казахский язык, основанный на латинице, в первую очередь использовался в начальных и средних школах и учебных заведениях, в то же время на всей территории страны были проведены мероприятия по его обучению и популяризации для всех взрослых. [2]

Между арабистами и латинистами начался настоящий ученый спор, суть которого заключается в том, чтобы понять, может ли латинский алфавит передать характеристики казахского языка. Казахстанский специальный комитет был создан для объединения латинской системы языка титульной нации. На конференции 1928 года была утверждена система алфавита казахского языка, основанная на латинице. Эта система состоит из 29 букв. [3]

\section{2. Кириммизашия в период Советского Союза}

В начале 1930-х годов советское правительство предложило кириллизацию письма. В 1937-1940 годах народы СССР отказались от уже использовавшейся системы латинского алфавита и перешли на кириллицу. В то время некоторые учёные считали, что латинский алфавит по фонетической структуре был беднее, чем система кириллического алфавита, потому что в латинском алфавите только всего 26 букв, многие из которых повторяются друг с другом, а в кириллическом алфавите 33 буквы, и ни одна из них повторяется с другими. Таким образом, если в качестве основы нового алфавита используется латинский алфавит, потребуется добавление дополнительных букв и буквенных знаков произношения.

Если латинизация символизирует революционный бум модернизации, шаг к мировой революции и победу советской модели «национальное государство», то кирилизация является символом единства народов, укрепления строительства единого государства и гомо- генизации букв. Кроме того, некоторые основные народы в Советском Союзе, такие как русские, белорусские и Украинские, традиционно использовали письменность, основанную на кириллице. В связи с этим возникла точка зрения, согласно которой создание письменности на основе латиницы, несомненно, означало бы разрыв или отчуждение связей между этими народами и другими народами, которые использовали или используют кириллицу.

Кириллица [4] была введена в Казахстане в середине 1930-х годов для создания единого советского пространства, в котором русский язык был бы общим языком. Алфавит казахского языка испытал еще одно преобразование. В 1940 году Казахстан утвердил окончательный вариант алфавита. Этот вариант содержит 41 букву: 32 русских буквы и 9 специальных знаков, которые выражают характеристики казахского языка. Национальные республики решили прекратить латинизацию алфавита или отказаться от уже латинизированных букв. Таким образом, алфавит большинства народов СССР, включая казахский, был кириллизирован.

\section{Причины перехода казахского языка на ^атиничу на нынешнем этапе}

После обретения независимости на постсоветском пространстве преобладала политика «русификации»: многие страны стали придавать особое значение традиционной культуре титульной нации, в качестве основного средства провели латинизацию алфавита титульной нации. Азербайджан, Туркменистан и Узбекистан стали инициаторами латинизации алфавита титульной нации.

В Казахстане давно обсуждали вопрос о переходе на систему латинского алфавита. В 2012 году первый президент Казахстана Н. Назарбаев дал поручение к 2025 году перевести государственный язык на латинскую графику. Согласно программной статье «Взгляд в будущее: модернизация общественного сознания» единый стандартный вариант казахского алфавита в новой графике должен быть утвержден в 2017 году. В 2017 году Президентом РК подписан Указ «О переводе алфавита казахского языка с кириллицы на латинскую графику»[5]. План мероприятий поэтапного перехода алфавита казахского языка на латинскую графику разработан до 2025 года, создано 4 рабочих группы по орфографическому, методическому, терминологическому, техническому и информационному сопровождению. В итоговом варианте, утвержденном Назарбаевым, апострофы отсутствуют, зато используются новые диакритические знаки наподобие умляутов (например á, ń), а также два диграфа (sh, ch). [6]

Казахстан постепенно перешел на латиницу в различных спорах и дискуссиях. Правительство Казахстана провёл политику латинизации. Основные причины за- 
ключаются в следующем:

- Во-первых, на национальном уровне переход Казахстана на латиницу основан на господствующем положении этой системы письменности в мире. Реформа алфавита в Казахстане - это не простая техническая проблема, которая тесно связана со строительством национального государства на данном этапе. Таким образом, Казахстан может лучше интегрироваться в западный мир и это способствует казахстанской модернизации. Связь Казахстана с международным сообществом также будет упрощена. [7]

- Во-вторых, с точки зрения национального самосознания латинизация алфавита Казахстана способствует сохранению национальных особенностей Казахстана, улучшению чувства национальной идентичности и возрождению национального духа Казахстана. Латиница давно уже использовалась в казахском языке в советский период. По словам самого Назарбаева, его главной целью является модернизация самосознания Казахстана, а укрепление национального самосознания является основным фактором повышения национальной конкурентоспособности, национальной идентичности и укрепления суверенитета.

- В-третьих, с точки зрения лингвистики, реформа алфавита не означает, что некоторые буквы механически заменяются другими буквами, поскольку это приведет к потере способности выражать характеристики произношения национального языка. Латинизация алфавита помогает повысить иммунитет казахского языка к иностранным языкам. Можно избежать преобразования иностранных слов в казахские слова через русский язык.

- В-четвертых, что касается самого алфавита, латиница является экономичной, быстрой, широко используемой и более удобной для компьютерной обработки. Латинский алфавит позволяет казахам быстрее и легче освоить английский язык, и Западу - казахский. Это даст Казахстану новые возможности и сделает его более открытым. Первый президент Назарбаев сказал, что кириллица в некоторой степени может искажать казахский язык, потому что сам казахский язык не имеет букв щ, ю, я и ь, поэтому и была введена система латинского алфавита. [8]

\section{Возможные отришательные последствия после ^атинизашии в Казахстане}

Переход на новый алфавит будет сопровождаться необходимостью принятия новых правил правописания. Новые правила правописания представляют передачу норм единиц лексики будет через латиницу. Казахстан начнет выпуск файлов латинского алфавита с 2021-2023 гг. А в период с 2024 по 2025 год в сферах офисных мате- риалов и средств массовой информации постепенно будет использоваться латинский алфавит. С продвижением реформы письма, в то время как реформа латинизации достигла большого результата, она, безусловно, принесет много негативных последствий, и также возникнут различные проблемы, вызванные реформой письма. Например:

1. Будет ситуация, когда сосуществуя кириллица и латиница. Для людей, за исключением подростков, это занимает много времени, чтобы полностью принять новую систему алфавита, и старшее поколение не привыкли к использованию латинского алфавита. Даже в Узбекистане, где давно уже использовался латинский алфавит, латиница используется только в сфере образования и в некоторых учреждениях. Многие газеты и журналы издаются на Кириллице, и большинство документов также печатаются на Кириллице, и в области средств массовой информации кириллица и латиница используются вместе. Будущее сосуществование кириллицы и латиницы в Казахстане также будет продолжаться долго. [9]

2. Это окажет огромное давление на финансы Казахстана. В Казахстане многие печатные издания, в которых собрано национальное культурное наследие, были написаны на кириллице в советское время, включая многочисленные учебные материалы для начальных и средних школ, классические литературные произведения и так далее. Для обновления всего текста СМИ и перевода книг, подготовки специалистов потребуются огромные расходы. По оценкам казахстанской газеты «Экспресс-К» 2011 года, стоимость латинизации казахского алфавита составляет от 2 до 100 миллиардов долларов, а согласно данным, опубликованным Комитетом по статистике Республики Казахстан в феврале 2018 года, ВВП Казахстана в 2017 году составил \$158,142 млрд., реформа латинизации оказала огромное давление на ограниченные национальные доходы.

3. Это может привести к снижению уровня образования и затруднить культурное наследие. В Узбекистане и Туркменистане результатом реформы является общее снижение интереса народа к чтению и снижение культурного и образовательного уровня людей. То же самое и в Казахстане, где пожилые и люди среднего возраста привыкли читать на кириллице, но это практически невозможно сейчас, и казахи старшего поколения снова станут неграмотными. В то же время, поскольку уже начался использоваться латинский алфавит, у молодых людей будут проблемы с чтением книг, изданных ранее на кириллице, что может привести к снижению уровня национального образования и снижению культурного уровня населения. Подобно тому, как советское правительство в 1920-х и 1940-х го- 
дах проводило реформы латинизации и кирилизации, культуре разных стран был нанесен большой ущерб. Это добровольное и недобровольное изменение привело к тому, что большое количество исторической культуры и информации, накопленной на основе предыдущей алфавитной системы, вышли из нормального обращения.

4. Реформа латинизации алфавита казахского языка может привести к ухудшению межэтнических отношений в стране. Доля русских в Казахстане больше, чем в других странах Центральной Азии. За алфавитной реформой стоит национальный вопрос. Популярность русского языка в Казахстане выше, чем казахского; число граждан, говорящих на русском языке в Казахстане, составляет от 70\% до 90\%, в этом случае введение латиницы может принести потенциальную опасность внутреннего культурного отделения от языка казахского народа[10]. Эта реформа письменности казахского языка, с одной стороны, затруднит освоение казахским языком других этнических групп и ускорит миграцию этих этнических групп за пределы Казахстана, с другой стороны, отказ от кириллицы в долгосрочной перспективе ослабит статус русского языка в Казахстане, затруднит межэтническое общение и создаст трудности для русскоязычных людей, живущих в Казахстане.

\section{Зак^ючение}

Основной целью реформы латинизации в Казахстане является модернизация самосознания Казахстана, укрепление национального самосознания, национальной конкурентоспособности, национальной идентичности и укрепление сознания суверенитета. Успешно достичь этих целей с помощью латинизации все еще остается большой проблемой. До настоящего времени модернизация Казахстана ещё осуществлялась на основе кириллицы. Основная опасность, стоящая перед Казахстаном, заключается в том, что он может повторить негативный опыт Узбекистана и Туркменистана. Ведь до сих пор Узбекистан и Туркменистан не достигли каких-либо особых достижений от латинизации, но их расстояние от России постепенно отдаляется. Реформа алфавита столкнется с различными опасностями. Если реформа не увенчается успехом, национальная конкурентоспособность Казахстана будет снижаться по мере снижения уровня образования. замена одной системы графики другой потребует много времени. Следовательно, латинизация казахстанских букв не будет полностью реализована в краткосрочной перспективе. Долгое время в будущем в Казахстане будет использоваться две системы графики: кириллица и латиница.

1. 吴宏伟. 中亚文字改革问题[]].语言与翻译,2002(3)

ЛИТЕРАТУРА

2. 胡振华. 中亚五国及其语言文字[J].中央民族大学学报,1996(5)

3. азахский алфавит: история[N]. https://www.nur.kz/1661560-kazakhskiy-alfavit-istoriya.html .2018

4. 吴宏伟. 中亚文字改革问题[J]. 语言与翻译,2002(3).

5. Назарбаев подписал указ о переходе Казахстана на латиницу[N].https://www.rbc.ru/rbcfreenews/59f29bae9a7947826bbf6ab4 .2018

6. Казахский алфавит: история. https://www.nur.kz/1661560-kazakhskiy-alfavit-istoriya.html .2017

7. Зачем Казахстану латиница? [N]. https://pikabu.ru/story/zachem_kazakhstanu_latinitsa_5531037.2018

8. Воробьев А. Почему Казахстану важен переход на латиницу и как на это реагировать России [N]. https://ru.sputniknews.kz/columnists/20180307/4837166/ perekhod-latinica-kazakhstan-reakciya-russia.html .2018

9. Назарбаев и новая азбука. Почему Казахстан переходит на латиницу?[N]. https://www.gosrf.ru/news/33358/ .2018

10. Рудой И. Казахстан переходит на латиницу[N]. https://www.proza.ru/2017/11/14/626.2018

○ Цзинь Жу (1476174134@qq.com). 